\title{
Hepatitis D in Patients Infected with Hepatitis B Virus in Cotonou: Characteristics and Risk Factors
}

\author{
Aboudou Raïmi Kpossou ${ }^{1,2^{*}}$, Frédéric Sogbo1,2, Alexandra Marilyn Oloukèmi Zomahoun1,2, \\ Khadidjatou Saké Alassan ${ }^{3}$, Rodolph Koffi Vignon 1,2, Comlan N'déhougbèa Martin Sokpon², \\ Fadel Sourokou', Jean Séhonou, ${ }^{1,2}$, Nicolas Kodjoh5, Dissou Affolabi ${ }^{1,2}$ \\ ${ }^{1}$ Faculty of Health Sciences, University of Abomey-Calavi (UAC), Abomey-Calavi, Benin \\ ${ }^{2}$ National and University Hospital Hubert Koutoukou Maga (CNHU-HKM), Cotonou, Benin \\ ${ }^{3}$ Department of Internal Medicine, University and Departmental Hospital of Borgou, Parakou, Benin \\ ${ }^{4}$ International Clinic of Cotonou Aupiais, Cotonou, Benin \\ ${ }^{5}$ National Hepatitis Control Program, Ministry of Health, Cotonou, Benin \\ Email:^kpossou.raimi@yahoo.fr, sogbofredias@yahoo.fr,marilynzomahoun@gmail.com,khadisak@yahoo.fr, rkvignon@yahoo.fr, \\ msokpon@yahoo.fr, fadelsourokou@yahoo.fr, jsehonou@yahoo.fr, nicolaskodjoh@gmail.com, affolabi_dissou@yahoo.fr
}

How to cite this paper: Kpossou, A.R., Sogbo, F., Zomahoun, A.M.O., Alassan, K.S., Vignon, R.K., Sokpon, C.N.M., Sourokou, F., Séhonou, J., Kodjoh, N. and Affolabi, D. (2020) Hepatitis D in Patients Infected with Hepatitis B Virus in Cotonou: Characteristics and Risk Factors. Open Journal of Gastroenterology, 10, 31-44. https://doi.org/10.4236/ojgas.2020.102004

Received: December 9, 2019

Accepted: January 17, 2020

Published: January 20, 2020

Copyright ( 2020 by author(s) and Scientific Research Publishing Inc. This work is licensed under the Creative Commons Attribution International License (CC BY 4.0).

http://creativecommons.org/licenses/by/4.0/ (c) (i) Open Access

\begin{abstract}
Introduction: Hepatitis D virus (HDV) is a satellite virus of hepatitis B virus (HBV). The purpose of this work was to describe the epidemiological, clinical and biological characteristics of HBV/HDV co-infection and the factors associated with this co-infection in Cotonou. Methods: This was a cross-sectional, descriptive study with prospective data collection. It took place from June to October 2016 at CNHU/HKM and the Atinkanmey Polyclinic in Cotonou. Subjects over 15 years of age with HBsAg and untreated for hepatitis were included consecutively. Sociodemographic, clinical and biological characteristics were collected for each patient using only a standardized questionnaire. Then, a blood sample was taken for the determination of anti-HDV antibodies as well as the viral load of HBV. Results: A total of 156 subjects were included, predominantly male (sex-ratio $=2$ ), and of median age 36 years. The majority were monogamous married (50\%) or single (41.7\%), and were from south of Benin (84.6\%). Most subjects were asymptomatic (49.4\%). The prevalence of total HDV antibodies was 3.9\% (6/156). In subjects with total HDV antibodies, the prevalence of HDV IgM was $33.3 \%$. Origin in northern Benin appears to be a risk factor for HDV infection $(p=0.042)$. Similarly, married subjects were statistically more infected with HDV than unmarried subjects $(p=0.002)$. Conclusion: The prevalence of HDV infection varies according to the origin of the patients and their marital status.
\end{abstract}




\section{Keywords}

Viral Hepatitis B, Viral Hepatitis D, Prevalence, Associated Factors

\section{Introduction}

Hepatitis B virus (HBV) infection is a global public health problem with nearly 257 million chronic carriers worldwide [1]. Sub-Saharan Africa is an area of high hepatitis B endemicity with an HBV prevalence of more than $8 \%$ [2]. It is a major cause of morbidity and mortality due to its complications with cirrhosis and hepatocellular carcinoma (HCC). The hepatitis delta virus (HDV) is a satellite virus of HBV [3]. Compared to hepatitis B alone, HDV infection results in much more severe acute or chronic hepatitis and faster progression to cirrhosis and HCC [4] [5].

VHD is an enveloped virus, generally spherical in shape and $36-43 \mathrm{~nm}$ in diameter. The viral envelope, consisting of the HBV envelope, surrounds a nucleocapsid made of an RNA molecule and a unique structural protein, the hepatitis delta antigen (HD Ag), which is essential for the assembly and propagation of HDV. There are two isoforms of $\mathrm{HD} \mathrm{Ag}$, the short form (HD-S Ag) and the long form (HD-L Ag) [6] [7]. Because of its characteristics that distinguish it from all viruses in the animal kingdom, the International Committee on Viral Taxonomy has proposed to classify HDV in the genus delta virus [8]. Eight genotypes of HDV (1 to 8), variously distributed, have been identified, of which genotypes 5 to 8 are predominant in West and Central Africa. HDV shares the same modes of transmission with HBV. These are either parenteral (post-transfusion or intravenous drug use contaminations), sexual (heterosexual or homosexual), or maternal-fetal (vertical or more often horizontal by perinatal superinfection of a new-born baby carrying the HBs antigen) [9] [10]. In Africa, people are generally infected during childhood and adolescence by vertical transmission from mother to child or by horizontal transmission through tattoos, acupuncture and ritual scarifications [11].

Despite missing data in many endemic regions of the world for HBV, the number of people infected with HDV is estimated at 15 to 20 million [12] according to the World Health Organization (WHO). In Benin, data on HDV infection are scarce. The only study published to our knowledge was on pregnant women with HBsAg at Saint Jean de Dieu Hospital in Tanguiéta in 2014. The prevalence of HDV infection in this population was estimated at $11.4 \%$ [13]. However, this study only included a limited sample of subjects (44 pregnant women) with HBsAg.

The objective of this study was to describe the epidemiological, clinical and biological characteristics of HBV/HDV co-infection and the factors associated with this co-infection in Cotonou.

\section{Methods}

This was a descriptive and analytical cross-sectional study with prospective col- 
lection, over a period of 4 months, from June to October 2016. It was carried out in two health centres in Cotonou: the hepato-gastroenterology department of the National and University Hospital-Hubert Koutoukou Maga (CNHU-HKM), the largest hospital in Benin, and the Atinkanmey Polyclinic (PA), one of the largest private clinics in the city.

The sample size was determined according to Schwartz's formula: $N=\sum^{2}[p(1-p)] / I^{2} \quad(N=$ the sample size, $\Sigma=$ the reduced deviation $(\Sigma=$ 1.96) at the 5\% threshold, $I=$ the precision granted (5\%), $p=$ the percentage of HDV antibody positivity (11.4\%)) considering the prevalence obtained in the study carried out at the Saint Jean de Dieu Hospital in Tanguiéta [13]. On the basis of these elements, the minimum number of subjects with HBsAg to be included in this study was 155 .

We included 156 subjects over 15 years of age with chronic HBsAg untreated for hepatitis, admitted to these centres during the period. Of these, 95 (60.9\%) were from CNHU-HKM and 61 (39.1\%) from PA. Prior informed consent of patients had been obtained. Sociodemographic, clinical and biological characteristics (transaminase levels, $\mathrm{HBe} \mathrm{Ag}$ and anti-HBe antibodies) were collected for each patient using a standardized questionnaire. Then, a blood sample was taken for the determination of total anti-HDV antibodies and IgM type anti-HDV antibodies as well as the viral load of HBV. Information not available for the subject, such as clinical and biological data, was collected in the subject's medical record. The detection of total anti-HDV antibodies was based on an enzymelinked immunosorbent competition technique. It was carried out using the ETIAB-DELTAK- $2^{\circledR}$ kit (Diasorin, France) and according to the manufacturer's protocol. The determination of anti-HDV IgM antibodies was performed on positive samples for total antibodies. The research was carried out using the ETI-AB-DELTA-IGMK- $2^{\circledR}$ kit (Diasorin, France) according to the manufacturer's protocol and is based on an immunometric technique with IgM capture. The HBV viral load was achieved using the $\operatorname{COBAS}^{\circledR} \operatorname{TaqMan}^{\circledR} \mathrm{HBV}$ kit (Roche, France) and according to the manufacturer's recommendations. The data were entered into the EpiData software version 3.1 and the data analysis was performed with Stata software version 12.0. For comparisons, the Fischer test was used, and the difference was considered significant for a $\mathrm{p}<0.05$.

The study was not submitted to an ethics committee. But the verbal consent of the patients included was obtained, and the data collected and treated in strict confidentiality.

\section{Results}

One hundred and fifty-six subjects met the inclusion criteria. The prevalence of total HDV antibodies was 3.9\% (6/156). In subjects with total HDV antibodies, the prevalence of HDV IgM was $33.3 \%(2 / 6)$.

For the remainder of this article, we will distinguish two types of subjects: subjects infected with HBV but not with HDV and who will be called HDV- and 
subjects infected with HBV and HDV and who will be called HDV+.

\section{Socio-demographic characteristics of the study population}

Of the 156 subjects with chronic HBV included, 104 (66.7\%) were male; the sex ratio was 2; the median age was 36 years with a prevalence of cases in the 25 to 44 age group (95/156 or $60.9 \%$ ). The majority of the subjects included were monogamous married $(78 / 156$ or $50 \%)$ or single $(65 / 156$ or $41.7 \%)$, and were from the South (132/156 or $84.6 \%)$.

The average age of the HDV+ subjects was $44 \pm 12.0$ years and the median was 39.5 years.

The socio-demographic factors associated with HDV infection are presented in Table 1. This table shows that married status $(p=0.042)$ and northern origin

Table 1. Sociodemographic and habitual factors associated with HDV infection.

\begin{tabular}{|c|c|c|c|}
\hline \multirow[b]{2}{*}{ Factors } & \multicolumn{2}{|c|}{ Status } & \multirow[b]{2}{*}{$\mathrm{p}$} \\
\hline & $\begin{array}{c}\text { HDV+ } \\
\text { n (\%) }\end{array}$ & $\begin{array}{l}\text { HDV- } \\
\text { n (\%) }\end{array}$ & \\
\hline \multicolumn{4}{|l|}{ Ages (in years) } \\
\hline $15-24$ & $0(0.00)$ & $21(14.00)$ & \multirow{5}{*}{0.195} \\
\hline $25-34$ & $2(33.33)$ & $44(29.33)$ & \\
\hline $35-44$ & $2(33.33)$ & $47(31.34)$ & \\
\hline $45-54$ & $0(0.00)$ & $26(17.33)$ & \\
\hline$>55$ & $2(33.33)$ & $12(8.00)$ & \\
\hline \multicolumn{4}{|l|}{ Sex } \\
\hline Male & $4(66.7)$ & $100(66.7)$ & \multirow{2}{*}{$>0.999$} \\
\hline Female & $2(33.3)$ & $50(33.3)$ & \\
\hline \multicolumn{4}{|l|}{ Marital status } \\
\hline Married monogamous & $4(66.7)$ & $74(49.4)$ & \multirow[t]{3}{*}{0.002} \\
\hline Married polygamous & $2(33.3)$ & $5(3.3)$ & \\
\hline Single & $0(0.0)$ & $65(43.3)$ & \\
\hline Divorced or widower & $0(0.0)$ & $6(4.0)$ & \\
\hline \multicolumn{4}{|l|}{ Origin } \\
\hline Native from the south & $3(50)$ & $129(87.2)$ & \multirow{2}{*}{0.042} \\
\hline Native from the north & $3(50)$ & $19(12.8)$ & \\
\hline \multicolumn{4}{|l|}{ Alcohol consumption } \\
\hline Not at all & $2(33.3)$ & $25(16.7)$ & \multirow[t]{4}{*}{0.535} \\
\hline Moderate & $1(16.7)$ & $65(43.3)$ & \\
\hline Important & $1(16.7)$ & $26(17.3)$ & \\
\hline Weaned or very rare & $2(33.3)$ & $34(22.7)$ & \\
\hline \multicolumn{4}{|l|}{ Sexual behaviour } \\
\hline Unique sexual partner & $3(50.0)$ & $100(66.7)$ & \multirow[t]{2}{*}{0.669} \\
\hline Multiple sexual partners & $3(50.0)$ & $50(33.3)$ & \\
\hline
\end{tabular}


( $\mathrm{p}=0.002)$ were statistically associated with HDV infection. In fact, according to Table 1, the prevalence of HDV was $3 / 132=2.3 \%$ in southern subjects while in northern subjects it was $3 / 22=13.6 \%$; and $6 / 85=7 \%$ in married subjects versus $0 \%$ in single, divorced or widowed subjects.

Clinical and biological characteristics of patients with chronic HBsAg by HDV status.

The medical history associated with HDV infection is shown in Table 2. None of the histories were statistically significantly associated with HDV infection.

With regard to symptomatology, in more than a majority of cases of HDV+, the disease was revealed by clinical manifestations, unlike HDV- (66.7\% versus $14.7 \%$ for digestive disorders, and $16.7 \%$ versus $14.7 \%$ for asthenia). The difference

Table 2. Medical history associated or not with HDV infection.

\begin{tabular}{|c|c|c|c|}
\hline \multirow[b]{2}{*}{ Factors } & \multicolumn{2}{|c|}{ Status } & \multirow[b]{2}{*}{$\mathrm{p}$} \\
\hline & $\begin{array}{c}\text { HDV+ } \\
\text { n (\%) }\end{array}$ & $\begin{array}{l}\text { HDV- } \\
\text { n (\%) }\end{array}$ & \\
\hline \multicolumn{4}{|c|}{ Sexually transmitted infections (STI) } \\
\hline History of STI & $2(33.3)$ & $34(22.7)$ & \multirow[t]{2}{*}{0.842} \\
\hline No history of STI & $4(66.7)$ & $116(77.3)$ & \\
\hline \multicolumn{4}{|l|}{ Tattoo } \\
\hline Yes & $1(16.7)$ & $3(2.0)$ & \multirow{2}{*}{0.293} \\
\hline No & $5(83.3)$ & $147(98.0)$ & \\
\hline \multicolumn{4}{|l|}{ Scarification } \\
\hline Yes & $6(10.0)$ & $102(6.0)$ & \multirow{2}{*}{0.210} \\
\hline No & $0(0.0)$ & $48(32.0)$ & \\
\hline \multicolumn{4}{|l|}{ Circumcision } \\
\hline Medicalized & $1(25.0)$ & $41(42.7)$ & \multirow{2}{*}{0.877} \\
\hline Non-medicalized & $3(75.0)$ & $55(57.3)$ & \\
\hline \multicolumn{4}{|l|}{ Surgical history } \\
\hline Yes & $0(0.0)$ & $40(26.7)$ & \multirow{2}{*}{0.326} \\
\hline No & $6(100.0)$ & $110(73.3)$ & \\
\hline \multicolumn{4}{|l|}{ Blood transfusion } \\
\hline Yes & $0(0.0)$ & $9(6.0)$ & \multirow{2}{*}{$>0.999$} \\
\hline No & $6(100.0)$ & $140(94.0)$ & \\
\hline \multicolumn{4}{|l|}{ Sickle cell disease } \\
\hline Yes & $0(0.0)$ & $4(2.7)$ & \multirow{2}{*}{$>0.999$} \\
\hline No & $6(100.0)$ & $146(97.3)$ & \\
\hline \multicolumn{4}{|l|}{ Diabetes } \\
\hline Yes & $0(0.0)$ & $4(2.7)$ & \multirow{2}{*}{$>0.999$} \\
\hline No & $6(100.0)$ & $146(97.3)$ & \\
\hline
\end{tabular}


was statistically significant $(\mathrm{p}=0.017)$ between the circumstances of discovery of viral hepatitis B in HDV+ subjects compared to HDV- subjects (Table 3).

Biologically, the median viral load in $\mathrm{HDV}+$ subjects was $54.5 \mathrm{IU} / \mathrm{mL}$, lower than that of $582 \mathrm{IU} / \mathrm{mL}$ in HDV subjects, with a statistically significant difference ( $p=0.02$; Table 3 ). On the other hand, the Ag HBe status, and the transaminase level are not statistically different between $\mathrm{HDV}+$ versus HDV-, according to Table 3 .

In the study population, $1.3 \%$ were $\mathrm{HCV}$-HBV co-infected $(2 / 151)$ and $0.7 \%$ were HIV-HBV co-infected (1/148). There were no cases of HBV-HCV-HIV co-infection. Among subjects infected with HDV, no cases of HIV co-infection or $\mathrm{HCV}$ co-infection were found and no significant differences between the two groups $\mathrm{HDV}+$ and HDV - for co-infections with HIV and HCV were observed (p > 0.999) (Table 3).

Table 3. VHD status of patients with chronic HBsAg by clinical and biological characteristics.

\begin{tabular}{|c|c|c|c|c|}
\hline \multirow{2}{*}{\multicolumn{2}{|c|}{ Characteristics }} & \multicolumn{2}{|c|}{ Status } & \multirow[b]{2}{*}{$\mathrm{p}$} \\
\hline & & $\begin{array}{c}\mathrm{HDV}+ \\
\text { n (\%) }\end{array}$ & $\begin{array}{l}\mathrm{HDV}- \\
\mathrm{n}(\%)\end{array}$ & \\
\hline \multirow{5}{*}{$\begin{array}{l}\text { Circumstances for the } \\
\text { discovery of hepatitis B }\end{array}$} & Voluntary testing & $1(16.6)$ & $76(50.7)$ & \\
\hline & Digestive disorders & $4(66.7)$ & $22(14.7)$ & 0.017 \\
\hline & Asthenia & $1(16.7)$ & $22(14.7)$ & \\
\hline & Blood Donation & $0(0.0)$ & $22(14.7)$ & \\
\hline & Cytolysis & $0(0.0)$ & $8(5.2)$ & \\
\hline \multirow[t]{6}{*}{ Co-infection } & Yes & $0(0.0)$ & $1(0.7)$ & $>0.999$ \\
\hline & HIV & & & \\
\hline & No & $6(100.0)$ & $141(99.3)$ & \\
\hline & Yes & $0(0.0)$ & $2(1.4)$ & $>0.999$ \\
\hline & VHC & $6(100.0)$ & $143(98.6)$ & \\
\hline & No & & & \\
\hline \multirow[t]{2}{*}{ Transaminases } & Elevated & $4(66.7)$ & $34(24.1)$ & 0.077 \\
\hline & Normal & $2(33.6)$ & $107(75.9)$ & \\
\hline \multirow[t]{7}{*}{ Replication markers } & $\mathrm{HBe} \mathrm{Ag}$ & & & \\
\hline & Negative & $6(100.0)$ & $127(91.4)$ & $>0.999$ \\
\hline & Positive & $0(0.0)$ & $12(8.6)$ & \\
\hline & anti-HBe antibodies & & & \\
\hline & Negative & $0(0.0)$ & $12(8.6)$ & $>0.999$ \\
\hline & Positive & $6(100.0)$ & $127(91.4)$ & \\
\hline & Median viral load HBV & 54.5 & 582 & 0.02 \\
\hline
\end{tabular}

\section{Discussion}

It appears from this work that the prevalence of anti-HDV antibodies was 3.9\% 
in patients followed for hepatitis B in Cotonou. This prevalence is higher than the $0.23 \%$ found in 2015 in Slovenia [14]. It is comparable to the prevalence of $3.5 \%$ reported in 2011 in France [5]. It is also comparable to the $3.38 \%$ found in 2015 in Burkina Faso by Sawadogo et al. [15]. However, it is lower than that previously found by De Paschale et al. [13] among pregnant women in 2014 in Tanguiéta in northern Benin (11.4\%). Similarly, higher HDV prevalences than ours have been reported in some sub-Saharan African countries: In Nigeria, Andernach et al. from 1998 to 2010 found a prevalence of $12.3 \%$ in a population of HBsAg carriers [16]. In Mauritania, Mansour et al., from 2008 to 2009 in pregnant women with HBsAg, found that total anti-HDV antibodies were present in 19.1\% [17]. Makuwa et al. in Gabon in 2005 [18] and Foupouapouognigni et al. in Cameroon in 2011 [19], observed prevalences of $15.6 \%$ and $17.6 \%$ respectively. Thus, the prevalence of HDV varies from one country to another, and within the same country from one region to another. This could be explained by differences in exposure to transmission risk factors (scarification, circumcision conditions, etc.).

In addition, the prevalence of anti-HDV IgM was 33.3\% in HDV+ subjects. This prevalence is lower than that of Ghamari et al. in 2012 in Iran [20] and Lunel-Fabiani et al. in 2009 [21] who noted prevalence of anti-HDV IgM of $66.7 \%$ and $57.1 \%$ respectively. On the other hand, it is higher than that found in China in 2014 by Liao et al., which was $6.5 \%$ [22].

The main risk factors for HDV infection identified in our study were marital status and ethnicity from northern Benin. These results are comparable to those of Mansour et al. in Mauritania in 2012 [23] in blood donors with HBsAg. These authors reported that subjects who were married more than once were more infected than subjects who were married once and those who were never married $(p=0.04)$. In this study, information on the number of times the subject was married was not collected. The fact that married subjects are more affected by HDV suggests an important role for sexual transmission of this virus. It should also be noted that married subjects are generally older than unmarried subjects and therefore have a higher cumulative risk of HDV infection than unmarried subjects. The fact that subjects from the North are more affected in this work reinforces the higher prevalence of HDV in northern Benin. Mansour et al. in Mauritania noted that subjects living in the desert were significantly more affected than those in other regions [17] [23]. The association between HDVs and northern origin could be justified by cultural practices such as scarifications, FGC and serial non-medicated circumcision that are reportedly more prevalent in the North than in the southern part of the country [24]. These data on HDV should be compared with the higher prevalence of HBV in northern Benin. Indeed, Kodjoh et al. had found in 2013 that the prevalence of hepatitis B was higher in the North than in the South of Benin with the highest prevalence in the departments of Atacora-Donga which was $20.15 \%$ compared to $9.08 \%$ in the Atlantic-Littoral departments where Cotonou is located [25]. 
Clinically, in the majority of HDV+ cases, the disease was revealed by clinical manifestations (digestive disorders in four cases, and asthenia in one case) unlike HDV- subjects in whom HBV was discovered predominantly through voluntary screening. These results are in line with the literature because chronic HDV infection is very rapidly progressive and leads to cirrhosis in $80 \%$ of cases [26].

Biologically, there was no statistically significant difference between the transaminase values of the two populations $(p=0.077)$. These results are similar to those of Yacoubi et al. in Tunisia in 2015 [27]. In contrast, Lunel-Fabiani et al. in Mauritania in 2012 [21] and Foupouapouognigni et al. in Cameroon in 2011 [19] found a statistically significant difference between the mean transaminase levels of VHD+ and VHD- subjects. The small size of our study population may explain the lack of difference. All VHD+ subjects were $\mathrm{HBe} \mathrm{Ag}$ negative. These results are similar to those of Yacoubi et al. [27] who found an $81 \%$ rate of $\mathrm{HBe}$ Ag negative subjects in VHD+ subjects and Ghamari et al. in Iran in 2012 who reported that all VHD+ subjects were $\mathrm{HBe} A g$ negative [20]. The HBV viral load was significantly lower in VHD+ subjects than in VHD- subjects ( $\mathrm{p}=0.02)$. These results are similar to those of Liao et al. in China [22] and Ghamari et al. in Iran in 2012 who reported low HBV viral loads in positive or even undetectable anti-HDV antibodies subjects for some [20]. Lunel-Fabiani et al. found that 81.6\% of subjects with positive anti-HDV antibodies had an HBV viral load < $2000 \mathrm{IU} / \mathrm{mL}$, but found no difference between the medians of HBV viral load in logarithm (log) of VHD+ and VHD- [21] subjects. It is indeed well known that VHD inactivates the replication of VHB [28].

The small number of VHD+ subjects found may have decreased the power of the study, particularly in the search for risk factors. Indeed, the sample size was calculated on the basis of the study carried out in Tanguiéta [13] where a higher prevalence had been observed. However, the present study is, to our knowledge, the first study that really allows us to assess the extent of HDV infection in $\mathrm{HBV}$-infected subjects in Cotonou. A larger study covering all departments of the country will make it possible to specify this prevalence at the national level and to refine the risk factors studied. The prevalence of anti-HDV IgM in VHD+ subjects may have been underestimated in our study. Indeed, anti-HDV IgM may be lacking in some black African subjects despite active virus replication, hence the interest in an HDV viral load [21]. This viral load was not available in our study. A total of 156 subjects with HBsAg were included, 95 (60.9\%) of whom came from CNHU-HKM and 61 (39.1\%) from Atinkanmey Polyclinic. These two sites were chosen because of their status and size. Indeed, the CNHU-HKM is Benin's public hospital of reference and the largest in the country in general and in Cotonou in particular. In addition, the Atinkanmey Polyclinic is one of the largest private clinics in Cotonou, with a hepato-gastroenterology service. Thus the choice of these two sites makes it possible to have a fairly representative sample of the population of subjects carrying HBsAg in Cotonou. 
As delta serology was not available locally in Benin, samples were usually sent to Europe via a private laboratory and its relatively high cost (60 US dollars) did not make it available to all patients. In this study, the test was set up in a multi-purpose national university laboratory and was performed free of charge for all subjects. This free service not only facilitated patient management but also contributed to a good representativeness of the sample by including in the study all eligible patients who agreed to participate.

\section{Conclusion}

This study shows that only $3.9 \%$ of HBV-infected subjects also had an HDV infection. The risk factors associated with HDV infection were North Benin origin and marital status (married subjects were more affected by infection). Subjects co-infected with HBV and HDV were more likely to have symptomatic disease and a lower B viral load.

\section{Conflicts of Interest}

The authors declare no conflicts of interest regarding the publication of this paper.

\section{References}

[1] World Health Organization (2017) Global Hepatitis Report 2017. WHO, Geneva, 83 p.

[2] Kramvis, A. and Kew, M.C. (2007) Epidemiology of Hepatitis B Virus in Africa, Its Genotypes and Clinical Associations of Genotypes. Hepatology Research, 37, S9-S19. https://doi.org/10.1111/j.1872-034X.2007.00098.x

[3] Flores, R., Ruiz-Ruiz, S. and Serra, P. (2012) Viroids and Hepatitis Delta Virus. Seminars in Liver Disease, 32, 201-210. https://doi.org/10.1055/s-0032-1323624

[4] Mansour, W., Ducancelle, A., Le Gal, F., et al. (2010) Resolution of Chronic Hepatitis Delta after 1 Year of Combined Therapy with Pegylated Interferon, Tenofovir and Emtricitabine. Journal of Clinical Virology, 47, 97-99. https://doi.org/10.1016/j.jcv.2009.09.027

[5] Gordien, E. (2015) L'infection par le virus de l'hépatiite delta. Donnnées françaises récentes. Bulletin épidémiologique Hebdomadaire, 19-20, 347-352.

[6] Farci, P. (2003) Delta Hepatitis: An Update. Journal of Hepatology, 39, 212-219. https://doi.org/10.1016/S0168-8278(03)00331-3

[7] Cunha, C. (2008) Structure and Replication of Hepatitis Delta Virus RNA. African Journal of Biotechnology, 7, 4911-4916.

[8] de Groot, R.J., Baker, S.C., Baric, R., et al. (2012) Virus Taxonomy: Ninth Report of the International Committee on Taxonomy of Viruses: Family Coronaviridae. Elsevier, Amsterdam, $1272 \mathrm{p}$.

[9] Rizzetto, M., Purcell, R. and Gerin, J. (1980) Epidemiology of HBV-Associated Delta Agent: Geographical Distribution of Anti-Delta and Prevalence in Polytransfused HBsAg Carriers. The Lancet, 315, 1215-1219. https://doi.org/10.1016/S0140-6736(80)91678-5

[10] Raimondo, G. (1982) Multicentre Study of Prevalence of HBV-Associated Delta In- 
fection and Liver Disease in Drug-Addicts. The Lancet, 319, 249-251. https://doi.org/10.1016/S0140-6736(82)90976-X

[11] Sultanik, P. and Pol, S. (2016) Infectious Diseases \& Therapy Hepatitis Delta Virus: Epidemiology, Natural Course and Treatment. Journal of Infectious Diseases and Therapy, 4, 2-7.

[12] Wedemeyer, H. and Manns, M.P. (2010) Epidemiology, Pathogenesis and Management of Hepatitis D: Update and Challenges Ahead. Nature Reviews Gastroenterology \& Hepatology, 7, 31-40. https://doi.org/10.1038/nrgastro.2009.205

[13] De Paschale, M., Ceriani, C., Cerulli, T., et al. (2014) Prevalence of HBV, HDV, HCV, and HIV Infection during Pregnancy in Northern Benin. Journal of Medical Virology, 86, 1281-1287. https://doi.org/10.1002/jmv.23951

[14] Jelen, M.M., Hošnjak, L., Štunf, Š., et al. (2016) Hepatitis D Virus Infection in Slovenian Patients with Chronic Hepatitis B Virus Infection: A National Prevalence Study and Literature Review. Acta Dermatovenerologica Alpina, Pannonica et Adriatica, 25, 49-54. https://doi.org/10.15570/actaapa.2016.14

[15] Sawadogo, A., Ouédraogo, A.S., Poda, A., et al. (2016) Séroprévalence de l'infection par le virus de l'hépatite $\mathrm{D}$ dans une population de donneurs de sang porteurs de l'Antigène $\mathrm{HBs}$ au Centre régional de transfusion sanguine de Bobo-Dioulasso. Journal Africain d Hépato-Gastroentérologie, 10, 31-33. https://doi.org/10.1007/s12157-015-0646-4

[16] Andernach, I.E., Leiss, L.V., Tarnagda, Z.S., et al. (2014) Characterization of Hepatitis Delta Virus in Sub-Saharan Africa. Journal of Clinical Microbiology, 52, 1629-1636. https://doi.org/10.1128/JCM.02297-13

[17] Mansour, W., Malick, F.F., Sidiya, A., et al. (2012) Prevalence, Risk Factors, and Molecular Epidemiology of Hepatitis B and Hepatitis Delta Virus in Pregnant Women and in Patients in Mauritania. Journal of Medical Virology, 83, 1186-1198. https://doi.org/10.1002/jmv.23336

[18] Makuwa, M., Mintsa-Ndong, A., Souquière, S., et al. (2009) Prevalence and Molecular Diversity of Hepatitis B Virus and Hepatitis Delta Virus in Urban and Rural Populations in Northern Gabon in Central Africa. Journal of Clinical Microbiology, 47, 2265-2268. https://doi.org/10.1128/JCM.02012-08

[19] Foupouapouognigni, Y., Noah Noah, D., Sartre, M.T. and Njouom, R. (2011) High Prevalence and Predominance of Hepatitis Delta Virus Genotype 1 Infection in Cameroon. Journal of Clinical Microbiology, 49, 1162-1164. https://doi.org/10.1128/JCM.01822-10

[20] Ghamari, S., Alavian, S.M., Rizzetto, M., et al. (2013) Prevalence of Hepatitis Delta Virus (HDV) Infection in Chronic Hepatitis B Patients with Unusual Clinical Pictures. Hepatitis Monthly, 13, e6731. https://doi.org/10.5812/hepatmon.6731

[21] Lunel-Fabiani, F., Mansour, W., Amar A.O., et al. (2013) Impact of Hepatitis B and Delta Virus Co-Infection on Liver Disease in Mauritania: A Cross Sectional Study. Journal of Infection, 67, 448-457. https://doi.org/10.1016/j.jinf.2013.06.008

[22] Liao, B., Zhang, F., Lin, S., et al. (2014) Epidemiological, Clinical and Histological Characteristics of HBV/HDV Co-Infection: A Retrospective Cross-Sectional Study in Guangdong, China. PLoS ONE, 9, e115888. https://doi.org/10.1371/journal.pone.0115888

[23] Mansour, W., Bollahi, M.A., Hamed, C.T., et al. (2012) Virological and Epidemiological Features of Hepatitis Delta Infection among Blood Donors in Nouakchott, Mauritania. Journal of Clinical Virology, 55, 12-16.

https://doi.org/10.1016/j.jcv.2012.05.011 
[24] Dovonou, C.A., Amidou, S.A., Kpangon, A.A., et al. (2015) Prévalence de l'hépatite B chez les personnes infectées par le VIH à Parakou au Bénin. Pan African Medical Journal, 20, 125. https://doi.org/10.11604/pamj.2015.20.125.6061

[25] Kodjoh, N. and Dansi, G. (2014) Rapport de la mission de collecte pour le calcul des prévalences des hépatite $\mathrm{B}$ et $\mathrm{C}$ chez les nouveaux donneurs de sang de 2012 au Bénin. Cotonou, Mnistère de la Santé, Direction nationale de la santé publique, 11 p.

[26] World Gastroenterology Organisation (2015) Global Guideline. Hépatite B. WGO, $39 \mathrm{p}$.

[27] Yacoubi, L., Brichler, S., Mansour, W., et al. (2015) Molecular Epidemiology of Hepatitis B and Delta Virus Strains That Spread in the Mediterranean North East Coast of Tunisia. Journal of Clinical Virology, 72, 126-132.

https://doi.org/10.1016/j.jcv.2015.10.002

[28] Sureau, C. and Negro, F. (2016) The Hepatitis Delta Virus: Replication and Pathogenesis. Journal of Hepatology, 64, S102-S116.

https://doi.org/10.1016/j.jhep.2016.02.013 


\section{Appendix}

Questionnaire: "Hepatitis delta in subjects infected with hepatitis B virus in Cotonou"

Record Number: [__ ] _ _ ] _ ] ] Date:

\begin{tabular}{|c|c|c|c|}
\hline No. & Questions & \multicolumn{2}{|l|}{ Answers-Codes } \\
\hline \multicolumn{4}{|c|}{ I. GENERAL INFORMATION } \\
\hline Q1. & Patient code & \multicolumn{2}{|l|}{$[\ldots][\ldots][\ldots][\ldots]$} \\
\hline Q2. & Age & \multicolumn{2}{|l|}{ [__ $]$} \\
\hline Q3. & Sex & $\begin{aligned} \text { Male } & =1 \\
\text { Female } & =2\end{aligned}$ & {[} \\
\hline Q4. & Level of study & $\begin{aligned} \text { None } & =1 \\
\text { Primary } & =2 \\
\text { Secondary } & =3 \\
\text { Higher } & =4\end{aligned}$ & [_] \\
\hline Q5. & Marital status & $\begin{aligned} \text { Single } & =1 \\
\text { Married monogamous } & =2 \\
\text { Married polygamous } & =3 \\
\text { Married polygamous } & =4 \\
\text { Not concerned } & =5\end{aligned}$ & {[} \\
\hline Q6. & If married, age at first marriage & \multicolumn{2}{|l|}{ [__ $]$} \\
\hline Q7. & Number of children & \multicolumn{2}{|l|}{[} \\
\hline Q8. & Nationality & $\begin{array}{r}\text { Beninese }=1 \\
\text { Other }=2\end{array}$ & [_] \\
\hline Q9. & If Beninese, specify your origin & $\begin{array}{l}\text { Native from the south }=1 \\
\text { Native from the north }=2\end{array}$ & {[} \\
\hline Q10. & $\begin{array}{l}\text { Profession } \\
\text { if other, please specify: }\end{array}$ & $\begin{aligned} \text { Employee } / \text { Public Servant } & =1 \\
\text { Reseller } / \text { Dealer } & =2 \\
\text { Worker/Craftsman } & =3 \\
\text { Farmer } & =4 \\
\text { Pupil/student } & =5 \\
\text { None } & =6 \\
\text { Other } & =7\end{aligned}$ & [_] \\
\hline Q11. & Place of residence & $\begin{aligned} \text { Cotonou } & =1 \\
\text { Outside Cotonou } & =2\end{aligned}$ & [_] \\
\hline \multicolumn{4}{|c|}{ II. Lifestyle } \\
\hline Q12. & $\begin{array}{l}\text { How often do you drink alcohol? } \\
\text { if other, please specify: }\end{array}$ & $\begin{aligned} \text { Never } & =1 \\
\text { Occasionally } & =2 \\
\text { Often } & =3 \\
\text { Other } & =4\end{aligned}$ & {[} \\
\hline Q13. & Do you use tobacco & $\begin{array}{l}\text { Yes }=1 \\
\mathrm{No}=2\end{array}$ & {[} \\
\hline Q14. & Do you inject drugs? & $\begin{array}{l}\text { Yes }=1 \\
\text { No }=2\end{array}$ & [__ \\
\hline Q15. & Do you have multiple sexual partners & $\begin{array}{l}\text { Yes }=1 \\
\text { No }=2\end{array}$ & [__ \\
\hline
\end{tabular}




\section{Continued}

\begin{tabular}{|c|c|c|c|}
\hline Q16. & $\begin{array}{l}\text { Have you ever had a sexually transmitted infection (go- } \\
\text { norrhea, chlamydia or syphilis)? }\end{array}$ & $\begin{array}{l}\text { Yes }=1 \\
\text { No }=2\end{array}$ & {$\left[\_\right]$} \\
\hline Q17. & Have you had sex with people of the same sex as you? & $\begin{array}{l}\text { Yes }=1 \\
\text { No }=2\end{array}$ & [_] \\
\hline Q18. & Do you have a tattoo? & $\begin{array}{l}\text { Yes }=1 \\
\text { No }=2\end{array}$ & [__ $]$ \\
\hline Q19. & Have you ever had any scarring & $\begin{array}{l}\text { Yes }=1 \\
\text { No }=2\end{array}$ & [_] \\
\hline Q20. & Was your circumcision medicalized & $\begin{aligned} \text { Yes } & =1 \\
\text { No } & =2 \\
\text { Not applicable } & =3\end{aligned}$ & [_] \\
\hline \multicolumn{4}{|c|}{ III. MEDICAL HISTORY } \\
\hline Q21. & Sickle cell disease & $\begin{array}{l}\text { Yes }=1 \\
\text { No }=2\end{array}$ & [_] \\
\hline Q22. & Hemophilia & $\begin{array}{l}\text { Yes }=1 \\
\text { No }=2\end{array}$ & {$\left[\_\right]$} \\
\hline Q23. & Dialysis & $\begin{array}{l}\text { Yes }=1 \\
\text { No }=2\end{array}$ & {$\left[\_\right]$} \\
\hline Q24. & Transfusion & $\begin{array}{l}\text { Yes }=1 \\
\text { No }=2\end{array}$ & [_] \\
\hline Q25. & Diabetes & $\begin{array}{l}\text { Yes }=1 \\
\text { No }=2\end{array}$ & [__ $]$ \\
\hline Q26. & Surgical history & $\begin{array}{l}\text { Yes }=1 \\
\text { No }=2\end{array}$ & [_] \\
\hline \multicolumn{4}{|c|}{ IV. CLINICAL DATA RELATED TO HEPATITIS B + DELTA } \\
\hline Q27. & Reason for consultation & & \\
\hline Q28. & Circumstances of HBV discovery & $\begin{aligned} \text { Blood donation } & =1 \\
\text { Screening } & =2 \\
\text { Digestive disorders } & =3 \\
\text { Asthenia } & =4 \\
\text { Cytolysis } & =5\end{aligned}$ & [_] \\
\hline Q29. & Asymptomatic & $\begin{array}{l}\text { Yes }=1 \\
\text { No }=2\end{array}$ & [_] \\
\hline Q30. & Jaundice & $\begin{array}{l}\text { Yes }=1 \\
\text { No }=2\end{array}$ & {$[\ldots]$} \\
\hline Q31. & Cirrhosis & $\begin{array}{l}\text { Yes }=1 \\
\text { No }=2\end{array}$ & [_] \\
\hline Q32. & Hepatocellular carcinoma & $\begin{array}{l}\text { Yes }=1 \\
\text { No }=2\end{array}$ & [_] \\
\hline Q33. & Were you ever hospitalized once? & $\begin{array}{l}\text { Yes }=1 \\
\text { No }=2\end{array}$ & {$[\ldots]$} \\
\hline Q34. & If so, for what reasons? & & \\
\hline Q35. & $\begin{array}{l}\text { Have you received injections from anyone other than a } \\
\text { health worker? }\end{array}$ & $\begin{array}{l}\text { Yes }=1 \\
\text { No }=2\end{array}$ & [_] \\
\hline
\end{tabular}




\section{Continued}

\begin{tabular}{|c|c|c|c|}
\hline Q36. & If so, by whom? & & \\
\hline \multicolumn{4}{|c|}{ V. SEROLOGICAL MARKERS } \\
\hline Q37. & Total HDV antibodies: & $\begin{aligned} \text { Positive } & =1 \\
\text { Négative } & =2\end{aligned}$ & [_] \\
\hline Q38. & IgM-type anti-HDV antibodies & $\begin{aligned} \text { Positive } & =1 \\
\text { Négative } & =2\end{aligned}$ & [_] \\
\hline Q39. & $\mathrm{HBeAg}$ & $\begin{aligned} \text { Positive } & =1 \\
\text { Négative } & =2\end{aligned}$ & [_] \\
\hline Q40. & anti-HBe antibodies & $\begin{aligned} \text { Positive } & =1 \\
\text { Négative } & =2\end{aligned}$ & [_] \\
\hline Q41. & Progressive profile of hepatitis B & $\begin{aligned} \text { Inactive carrier } & =1 \\
\text { Immunotolerant } & =2 \\
\text { Chronic active hepatitis } & =3\end{aligned}$ & [_] \\
\hline Q42. & HCV co-infection & $\begin{aligned} \text { Yes } & =1 \\
\text { No } & =2\end{aligned}$ & [_] \\
\hline Q43. & HIV co-infection & $\begin{array}{l}\text { Yes }=1 \\
\text { No }=2\end{array}$ & [_] \\
\hline Q44. & Transaminasemia & $\begin{aligned} \text { Normal } & =1 \\
\text { Elevevated } & =2\end{aligned}$ & [_] \\
\hline Q45. & HBV viral load & ] & \\
\hline
\end{tabular}

